\title{
LiteratuRe
}

Esch, G. J. vaN and P. C. HART: Landbouwk. Tijdschr. 65 (1953a) 195.

- -, - - : Landbouwk. Tijdschr. 65 (1953b) 738.

Frens, A. M. : Landbouwk. Tijdschr. 61 (1949) 916.

HART, P. C. : Tijdschrift voor Diergeneeskunde 78 (1953) 929.

- - : Tijdschrift voor Diergeneeskunde 79 (1954a) 91.

- - : Tijdschrift voor Diergeneeskunde 79 (1954b) 517.

Leeuwen, P. H. van and P. C. Hart : Chem. Weekbl. 48 (1952) 829.

\section{SOME OBSERVATIONS ON THE GENERATIVE DEVELOPMENT OF THE PEANUT ${ }^{1}$ )}

\author{
A. VAN ROSSEM and G. G. BOLHUIS
}

Laboratory of Tropical Agriculture, Agricultural University, Wageningen

\section{INTRODUCTION}

These observations were made on plants of the variety Schwarz 21, which variety belongs to the so-called Spanish group. It was selected at Buitenzorg (v. D. GIessen and Govers, 1939). The plants under study were grown in thermostat boxes under 12 hours' illumination from high-pressure mercury lamps (Philips HO 2000). The temperature was kept at $30^{\circ} \mathrm{C}$.

\section{Results}

Young plants showed simultaneous growth of the main axis and of cotyledonous buds and the first two axillar buds into stalks which are similar to the main axis. The development of the said buds seems to be at least as important as that of the main axis. These buds give always rise to leaves, in the axis of which are inflorescenses. Although the plants develop symmetrically, it was noted that one side is always somewhat more advanced in development. Flowering starts at the 23 rd day after sowing : the first flower always developing from the axillar buds of the first lateral stalks. At that moment the plants possesses 10-12 developed leaf packets with altogether $40-48$ leaflets. The greater part of the flowers are provided by the first lateral stalks.

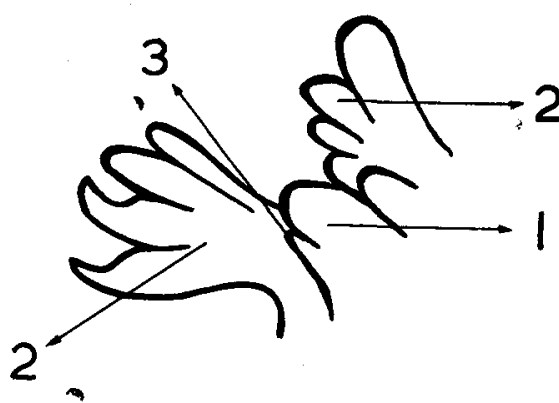

Fig. 1. Stem apex with vegetative CONE, 1. Growing point. 2. Leaf primordia in development. 3. New leaf primordium.

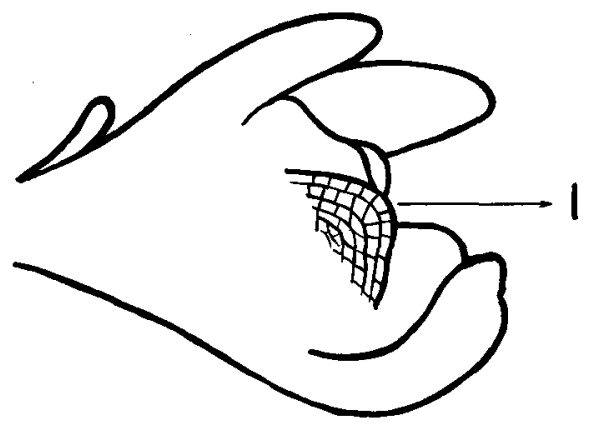

Fig. 2. AXILLARY BUD WITH FLOWER INITIATION AND TYPICAL "ClaW" ShaPE OF THE BRACTS. 1. Generative growing point.

1) Received for publication August 31, 1954. 
Microscopial investigation of the stem apex showed the well-known difference between the growing point in the vegetative phase and those already in the generative phase: the latter ones have a more flattened appearance. The vegetative cone is tapered and usually surrounded by leaf packets in abscission (Fig. 1), the generative cone has no surrounding leaf packets and soon floral parts are distinguishable (Fig. 2).

Investigation of the axillar buds of the cotyledons pointed to the fact that in the earliest phases of development there exists floral initiation in the peanut plant (Fig. 3). Notwithstanding this early presence of a floral apex, the flowering proper starts only three weeks after sowing: this, presumably, is connected with the assimilation capacity of the plant.

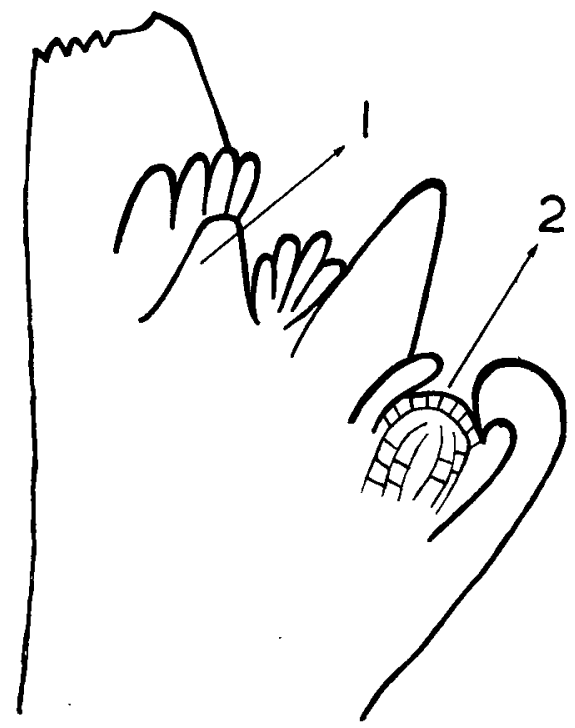

Fig. 3. Cotyledonous Bud. 1. Vegetative growing point. 2. Generative growing point (flower initiation).

\section{REFERENCE}

Gressen, C. vAN DER and A. Govers: De aardnootvariëteit Schwarz 21 en haar resistentie tegen slijmziekte. Landbouw 15 (1939) 183-188. 